\title{
Between Memory and Desire
}

The Middle East in a Troubled Age

\section{R. Stephen Humphreys}

"An outstanding piece of work on the relationship between secular and religious politics in the Middle East. It brings together medieval, modern, and contemporary Middle East history beautifully in a book of exceptional clarity and depth. Humphreys is nonjudgmental yet candid, focused yet comprehensive. His integration of early Islamic and contemporary history is novel, bold, and successful."

-Leila Fawaz, author of An Occasion for War $\$ 29.95$ cloth

\section{Tortured Confessions}

Prisons and Public Recantations

\section{In Modern Iran}

\section{Ervand Abrahamian}

"Abrahamian's cogent and engrossing history of imprisonment and resistance chronicles the continuities and ruptures of modern Iran from the vantage points of its shackled dissidents."

一Joe Stork, Advocacy Director, Human Rights

Watch, Middle East and North Africa Division $\$ 45.00$ cloth, $\$ 16.95$ paper

\section{Lawrence of Arabia}

\section{A Film's Anthropology}

\section{Steven C. Caton}

"Lawrence of Arabia is one of the most interesting

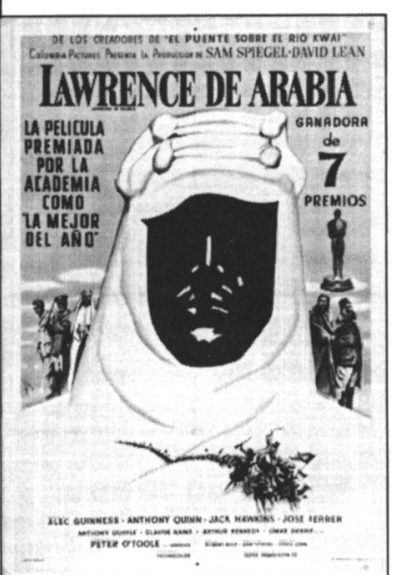
books on cultural criticism I have read recently. Its theme overlaps the fields of anthropology, cultural studies, and post-colonial criticism in fascinating ways. A splendid read." - Talal Asad, author of Genealogies of Religion $\$ 50.00$ cloth, $\$ 19.95$ paper

\section{NEW IN PAPERBACK}

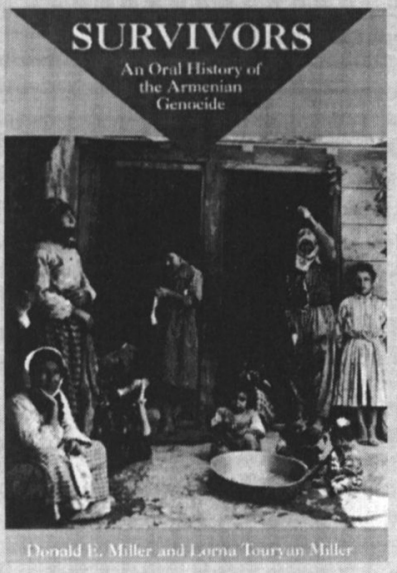

\section{Survivors}

An Oral History of the Armenian Genocide Donald E. Miller and Lorna Touryan Miller "The Millers... are fair in their judgments and do not suppress evidence of the humanity and kindness to the Armenians of many Turks who opposed the deportation and bloodshed. Provides additional evidence, if such is needed, of one of the greatest tragedies of modern history." -New York Times Book Review

$\$ 17.95$ paper

At bookstores or order 1-800-822-6657

\section{University of California Press}

www.ucpress.edu 


\section{NEW FROM PENGUIN PUTNAM INC.}
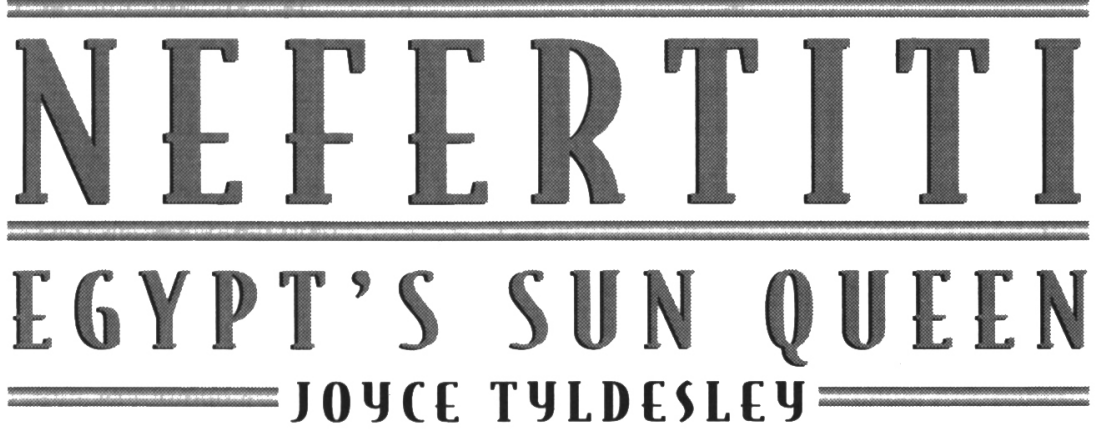

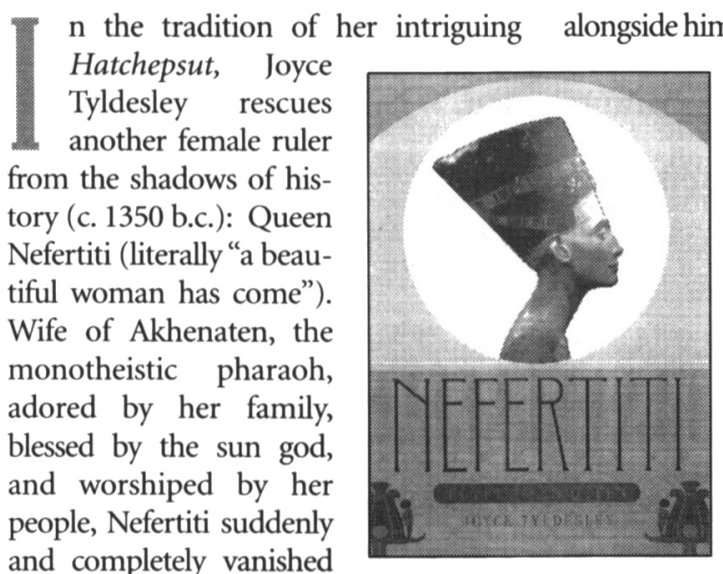
from the record. She may have been banished by her husband, or promoted to rule photos, 38 figures, 2 maps. been the éminence grise behind the young Tutankhamen, her son-in-law.

Tyldesley synergizes archeological, textual, and artistic evidence in a detailed discussion of Nefertiti's life and times at the ephemeral and heretical Amarna court, and radically re-creates the woman who was the most influential in the Bronze Age world. $16 \mathrm{pp}$. of $\mathrm{b} / \mathrm{w}$

Viking 0-670-86998-8

$\$ 27.95$

\section{ALSO BY JOYCE TYLDESLEY:}

\section{HATCHEPSUT: THE FEMALE PHARAOH}

"An absorbing scholarly biography, based on a meticulous review of the archaeological record, of a remarkable woman who ruled as pharaoh for 20 years in Egypt's Eighteenth Dynasty. Tyldesley works closely from surviving texts and fragmentary monuments to recreate vividly an outstanding woman of the ancient past."-Kirkus. 16 pp. of b/w photos, 52 line drawings, 2 maps.
Penguin
$304 \mathrm{pp}$.
0-14-024464-6
$\$ 14.95$

\section{DAUGHTERS OF ISIS: WOMEN OF ANCIENT EGYPT}

"This splendidly clear, full and often amusing account of ancient Egypt would surely have met with the approval of Herodotus himself."-Sunday Telegraph.

Photographs, drawings, maps.
Penguin
352 pp.
0-14-017596-2
$\$ 12.95$ 


\section{The Aqquyunlu}

Clan, Confederation, Empire

Revised and Expanded Edition

John E. Woods

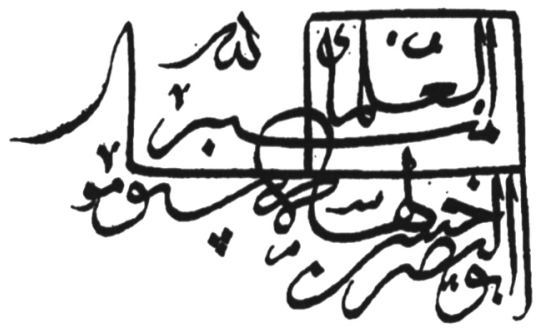

Focusing on the years 1378 to 1508 , John Woods traces the Aqquyunlu confederation's rise from clan, through civil war, consolidation, and decline, drawing upon a wide range of Arabic, Persian, and Turkish sources. Long unavailable, The Aqqüyunlu is still the primary Englishlanguage work on this fascinating period.

12 maps, 7 halftones, 18 line drawings

0-87480-565-1 Cloth, $\$ 45.00$

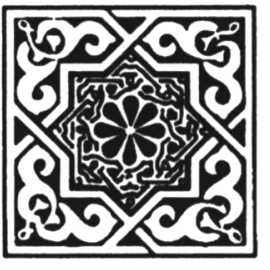

\section{Islamic Legal Orthodoxy}

Consensus and the Development of the Twelver Shiite Legal Madhhab

\section{Devin J. Stewart}

"This book will change the way its readers think about Islamic law, about the relations between Shi' ism and Sunnism. Perhaps most importantly, they will have to rethink the glib clichés about the doctrine of consensus that are even today carved into the standard introductory textbooks on Islam."

-A. Kevin Reinhart, Dartmouth College

0-87480-551-1 Cloth, $\$ 40.00$

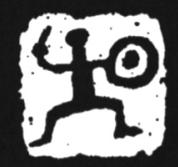

\section{The University of Utah Press} (800) 773-6672 fax (801) 581-3365 1795 E. South Campus Drive, \#101 Salt Lake City, Utah 84112-9402 info@upress.utah.edu www.upress.utah.edu 
The Middle East Studies Association of North America, Inc. (MESA) was organized in 1966 by a group of American and Canadian scholars on the Middle East to

- promote high standards of scholarship and instruction in this area;

- facilitate communication among scholars through meetings and publications; and

- foster cooperation among persons and organizations concerned with the scholarly study of the Middle East.

MESA focuses on the study of the Middle East since the rise of Islam, principally from the viewpoint of the humanities and the social sciences. Its membership is international.

Persons of scholarly training and/or achievement in Middle East studies are eligible to become Full Members ( $\$ 75$, Retired $\$ 35$, Joint $\$ 100)$. Other categories of membership are Associate $(\$ 75)$, Student (\$35), and Institutional (\$500). Each membership is on a calendar-year basis. Membership includes subscriptions to the International Journal of Middle East Studies, the MESA Bulletin, and the MESA Newsletter. Application forms may be obtained from the MESA Secretariat, 1643 East Helen Street, University of Arizona, Tucson, Arizona 85721, telephone (520) 621-5850, fax (520) 626-9095.

MESA is a nonprofit corporation with tax-exempt status. Contributions to the Association are deductible under both US Federal and British income tax regulations.

Honorary Fellows: Halil Inalcik, Charles Issawi, Majid Khadduri, Ann K.S. LAMBTON, MUHSIN S. MAHDI, ANDRÉ RAYMOND,

MaXime Rodinson, ANNEMARIE SCHIMMEL, W. MONTGOMERY WATT

Past President: PHILIP C. KHOURY

President: BARBARA FREYER STOWASSER

President-Elect: JERE L. BACHARACH

Directors:

1997-1999: Virginia AKSan, Peter Sluglett

1998-2000: FATMA MÜGE GÖÇEK, MERVAT F. HATEM

1999-2001: IrENE A. BIERMAN, ElLEN-FAIRBANKS D. BODMAN

Executive Director \& Treasurer: ANNE H. BETTERIDGE

The following publications are available from the MESA Secretariat:

- Directory of Graduate and Undergraduate Programs and Courses in Middle East Studies in the United States, Canada, and Abroad. Middle East Studies Association, published biennially.

- Middle East Materials for Teachers, Students, Non-Specialists, ed. by Catherine Jones. Middle East Outreach Council, 1988.

- Evaluation of Secondary-Level Textbooks for Coverage of the Middle East and North Africa, 3rd edition, ed. by Elizabeth Barlow. Middle East Outreach Council, 1994.

- Women in the Muslim World: A Bibliography, ed. by Herbert Bodman, Jr. Association for Middle East Women's Studies, 1991.

- Bibliography on Women in Yemen, ed. by Marta Colburn. American Institute for Yemeni Studies, 1992.

- Edited Works and Collections on the Middle East. Annual, Vol 1-8(1988-94)

- On-Line Research \& Teaching Resources for Middle East Studies, ed. by Jon W. Anderson. Middle East Studies Association, 1994

- MESA Bulletin Index: Vols. 1-20, 1967-1986.

- Back issues of the MESA Bulletin and Annual Meeting Programs. 


\section{LYNNE RIENNER PUBLISHERS}

\section{Islam in Contemporary Egypt:}

Civil Society vs. the State

Denis J. Sullivan and Sana Abed-Kotob

"A remarkably reliable, accessible, and dispassionate account of the very complex relationship of Islamic political movements and Egypt's authoritarian regime.... informative and engrossing." -Raymond W. Baker • hc $\$ 49.95 \bullet p b \$ 19.95$

The Nile: Histories, Cultures, Myths edited by Haggai Erlich and Israel Gershoni "An important and useful book." - Harold Marcus Forthcoming_July $1999 \bullet$ hc $\$ 55$

\section{New Edition!}

Men in the Sun and Other Palestinian Stories Ghassan Kanafani, translated by Hilary Kilpatrick • pb $\$ 11.50$

\section{Legislative Politics in the Arab World:} The Resurgence of Democratic Institutions Abdo Baaklini, Guilain Denoeux, and Robert Springborg "Legislatures in Arab countries have too often been dismissed as little more than rubber stamps for dictators.... This well-crafted study shows a more complex reality."-William B. Quandt $h c \$ 59.95 \bullet p b \$ 22.50$

\section{Islamism, Secularism, and Human Rights in the Middle East Mahmood Monshipouri}

"Interesting and well-written.... scholars will find cogent and compelling arguments on certain hot topics."-Susan Waltz hc $\$ 53$

\section{Minorities and the State in the Arab World edited by Ofra Bengio and Gabriel Ben-Dor • he $\$ 49.95$}

\section{Political Liberalization and}

Democratization in the Arab World:

Vol. 2, Comparative Experiences

Bahgat Korany, Rex Brynen, and Paul Noble

"A comprehensive survey of forces working toward and against democratization in the Middle East, and makes a major contribution to constructing theories about transitions to democracy."-Tansa George Massoud • hc $\$ 55 \bullet p b \$ 22$
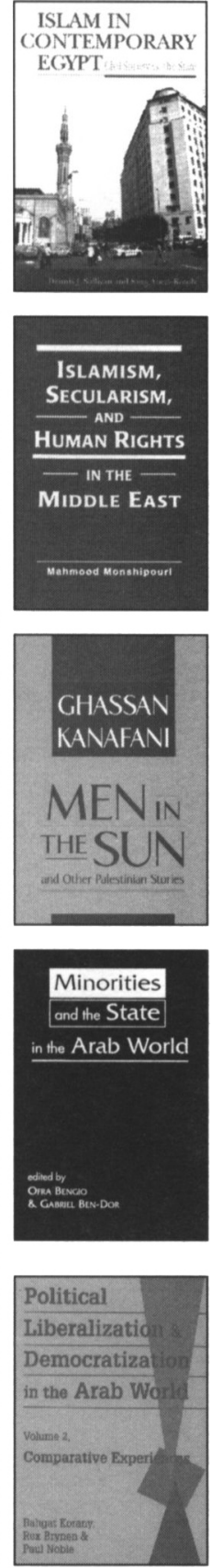